\section{Наталія МАДЗІГОН}

\section{Вплив практики Европейського суду 3 прав людини на реалізацію норм міжнародного гуманітарного права}

\begin{abstract}
Стаття присвячена аналізу практики Европейського суду 3 прав людини у контексті реалізації норм міжнародного гуманітарного права. Розглянуто ключові рішення Європейського суду з прав людини, які стосувалися порушень статей 1, 2 та 5 Конвенції про захист прав людини і основоположних свобод, та розглядались у контексті реалізації норм міжнародного гуманітарного права.

Ключові слова: ЄСПЛ, права людини, міжнародне гуманітарне право, військові дії, право на життя.

The article is devoted to the analysis of the practice of the European Court of Human Rights in the context of the implementation of the norms of international humanitarian law. The key judgments of the European Court of Human Rights concerning violations of Articles 1, 2 and 5 of the Convention for the Protection of Human Rights and Fundamental Freedoms considered by the Court in the context of the implementation of the rules of international humanitarian law were analyzed.
\end{abstract}

Keywords: ECHR, human rights, international humanitarian law, military actions, right to life.

Питання належного виконання зобов'язань держав за міжнародним гуманітарним правом (далі - МГП) тісно пов' язано з виконанням і дотриманням ними норм інших галузей міжнародного права, перш за все норм, спрямованих на захист прав людини. У цьому контексті дуже важливо дослідити взаємозв' язок цих галузей міжнародного права. Яскраво ілюструє цей взаємозв' язок практика Європейського суду з прав людини (далі - ССПЛ), який у своїх рішення неодноразово давав тлумачення Конвенції про захист прав людини і основоположних свобод (далі - ЄКПЛ) [1] у контексті застосування ії норм у період військових дій та воєнної окупації. Ключовими у цьому контексті є дві статті: стаття 1, тлумачення якої дає можливість визначити загальні ключові підходи до розуміння того, яким чином взагалі застосовувати Конвенцію, та стаття 2, яка гарантує основоположне право людини - право на життя.

Під час написання статті було досліджено наукові досягнення вітчизняних та зарубіжних вчених. Зокрема, це такі вчені, як Толочко О., Парк I. (Park I.), Гом'єн Д., Досвальд-Бек Л. (Doswald-Beck L.), Русінова В. та ряд інших.

Основними завданнями цієї статті є визначення особливостей:

- впливу практики Європейського суду з прав людини на реалізацію норм міжнародного гуманітарного права;

- конвергенції МГП та норм міжнародного права прав людини.

Стаття 1 ЄКПЛ покладає на держави зобов'язання поважати права людини. Воно передбачає, що сторони Конвенції гарантують кожному, хто перебуває під їхньою юрисдикцією, права і свободи, визначені в розділі I документа. Перше питання, яке постає у контексті застосування цієї статті при реалізації норм МГП це, яка саме держава несе відповідальність за належне виконання положень Конвенції в цілому, тобто питання юрисдикції.

У цьому відношенні ССПЛ у рішенні у справі, яка стосувалась подій, пов' язаних з Придністровським конфліктом, Catan and others v. Republic of Moldova and Russia, надав роз'яснення, що одним 3 винятків з принципу, що юрисдикція за статтею 1 обмежується територією власної держави, є ситуація, коли

УДК 341.3

https://doi.org/10.36952/ujil.2019.4.61

() Н. Мадзігон, 2019
МАДЗІГОН Наталія Вікторівна аспірант кафедри міжнародного права Інституту міжнародних відносин Київського національного університету імені Тараса Шевченка 
держава внаслідок військових дій (законних або незаконних) здійснює ефективний контроль над територією за межами своє території. Обов'язок забезпечити, у такому випадку права і свободи, викладені в Конвенції, випливає з самого факту такого контролю, незалежно від того, чи здійснюється вона його безпосередньо, через власні збройні сили або через підпорядковані їй місцеві адміністрації. При цьому той факт, що місцева адміністрація «виживає» за рахунок військової або іншої підтримки держави, тягне за собою відповідальність саме цієї держави за ії політику та дії адміністрації. Таким чином, на думку ССПЛ, держава, яка здійснює контроль, несе відповідальність за статтею 1 щодо забезпечення в межах території, що знаходиться під іiі контролем, усього ряду основних прав, визначених у Конвенції та тих додаткових протоколах, які вона ратифікувала. Вона також несе відповідальність за будь-які порушення цих прав [2]. Відповідно у контексті застосування норм МГП ми маємо практику, яка свідчить про виняток з принципу обмеження юрисдикції виключно територією власної держави.

Крім того, у практиці ЄСПЛ було розглянуто питання екстериторіальної юрисдикції у випадку застосування сили агентами держави, які діють поза межами ії території. Так у рішенні по справі Al-skeini and others $v$. the United Kingdom ССПЛ зазначив, що у деяких випадках застосування сили 3 боку агентів держави, які працюють поза ії територією (законно чи незаконно) підпадає під контроль держави та на такі дії розповсюджуватиметься ії юрисдикція. Суд відзначив, що, якщо держава через своїх агентів здійснює контроль і повноваження щодо окремої особи, вона таким чином реалізує щодо неї свою юрисдикцію. Відповідно держава зобов'язана за статтею 1 забезпечити цій особі права і свободи відповідно до розділу I Конвенції [3].

Разом з тим, у справі Issa and others v. Turkey Суд зазначив, що підзвітність держави в таких ситуаціях випливає з того, що стаття 1 Конвенції не може тлумачитися таким чином, щоб дозволити державі-учасниці здійснювати порушення Конвенції на території іншої держави, яке така особа не могла б здійснити на ії власній території. Тому існує необхідність доведення таких дій у кожному конкретному випадку. Справа Issa and others v. Turkey стосувалися іракських пастухів, які були заарештовані та вбиті турецькими солдатами під час турецької військової операції на півночі Іраку в 1995 році. На думку Суду, незважаючи на велику кількість солдат, які брали участь у цій операції, Туреччина не здійснювала ефективний загальний контроль над цією територією, оскільки не було надано достатніх доказів того, що турецькі збройні сили проводили операції в відповідній географічній зоні, де були присутні жертви, Суд дійшов висновку, що безпосередні жертви не перебували під юрисдикцією Туреччини [4]. Разом з тим, практика Суду з цього питання є неоднозначною і цілком очевидно залежить від фактичних обставин справи. Так, у справі Jaloud v. the Netherlands ЄСПЛ дійшов протилежного висновку порівняно із справою Issa and others v. Turkey, та розширив поняття екстериторіальної юрисдикції, зазначивши, що статус «окупаційної влади», згаданий у статті 42 Гаазької Конвенції про закони і звичаї війни на суходолі [5], per se не є вирішальним у питанні про юрисдикцію для цілей статті 1 Конвенції [6, с. 62]. Такого висновку Суд дійшов, виходячи з конкретних обставин цієї справи. У ході військових дій у в південно-східному Іраку уряд Нідерландів передав свої війська під командування офіцера збройних сил Сполученого Королівства. Відповідно постало питання юрисдикції. Суд у цій справі зазначив, що Нідерланди не втратили юрисдикцію лише за фактом передачі оперативного контролю офіцеру Великої Британії.

Таким чином ССПЛ у своїй практиці визнав ряд виняткових обставин, які можуть призвести до поширення юрисдикції держави за межі ії власних територіальних кордонів. У кожному випадку питання про те, чи існують виняткові обставини, які обгрунтовують висновок ССПЛ про те, що держава здійснює екстериторіальну юрисдикцію, мають вирішуватися з урахуванням конкретних обставин.

Практика Суду також свідчить, що під час міжнародного збройного конфлікту права, що гарантуються Конвенцією, мають застосовуватися з урахуванням контексту та положень міжнародного гуманітарного права. Такі положення тлумачиться у світлі статті 15 Конвенції, яка дозволяє відступ від зобов'язань під час надзвичайної ситуації. Так у справі Hassan v. the United Kingdom, що стосувалася затримання і арешту Британськими військами громадянина Іраку Тарека Хасана, якого потім було знайдено мертвими за нез'ясованих обставин, сторона-відповідач апелювала до того, що включення до Конвенції статті 15 у жодному разі не вказує на те, що під час війни або надзвичайної ситуації, що загрожує життю нації, зобов'язання за Конвенцією тлумачаться ідентично мирному часу. Будь-який аргумент про те, що статті Конвенції, зокрема стаття 5, будуть застосовуватись незалежно від контексту та норм міжнародного гуманітарного права, що регулюють затримання підозрюваних учасників бойових дій, створює ризик зменшення захисту, який гарантується учасникам бойових дій або цивільному населенню за МГП. ССПЛ встановив у цій справі, що гарантії згідно зі статтею 5 повинні тлумачитися та застосовуватися з урахуванням контексту та положень міжнародного гуманітарного права, і тільки тоді, коли це конкретно стверджується державою-відповідачем [7]. 
Хоча у рішенні по цій справі ЄСПЛ більшістю голосів суддів визнав, що норми МГП мають характер lex specialis по відношенню до Конвенції, не можна не погодись з спільною окремою думкою суддів Спано (Spano), Ніколау (Nicolaou), Біанку (Bianku) та Калайджєва (Kalaydjieva), які констатують наявність колізії норм двох галузей міжнародного права: прав людини і МГП. У своїй окремій думці вони відзначили: «повноваження інтернованого згідно з Третьою та Четвертою Женевськими конвенціями, на які посилається Уряд як дозволену підставу для взяття під арешт та затримання Тарека Хасана, перебувають у безпосередньому протиріччі з пунктом 1 статті 5 Конвенції. Суд не має у своєму розпорядженні жодного законного інструментарію, як суду, щоб виправити це зіткнення норм. [...] рішення більшості не відображає точного розуміння обсягу та сутності основного права на свободу відповідно до Конвенції...» [7, с.66].

У цьому контексті слід зазначити, що колізії між СКПЛ, та в цілому нормами, спрямованими на захист прав людини, та нормами МГП є системними. Найяскравіше це можна проілюструвати на прикладі основоположного права людини - права на життя, яке відповідно закріплено у статті 2 ЄКПЛ. Зміст та обсяг права на життя, а також зміст негативних, а особливо позитивних зобов'язань держави що реалізації цього права, багато в чому залежить від: 1) виду конфлікту (міжнародний (неміжнародний) збройний конфлікт, ситуацій насильства всередині держави, що не досягають рівня збройного конфлікту); 2) правового статусу суб'єктів та в деяких випадках поведінки таких суб'єктів.

У МГП виділяють комбатантів, некомбатантів та цивільне населення. Загалом, як вказують науковці, право війни засновано на строгому розділенні їх правового статусу [8, с. 21]. При визначенні цих категорій Протокол І прийняв так званий «негативний підхід», який повинен гарантувати, що кожна людина в умовах збройного конфлікту відноситься до тієї чи іншої категорії [9, с. 372].

Відповідно до п. 2 ст. 43 Протоколу І особи, які входять до складу збройних сил сторони, що перебуває в конфлікті (крім медичного і духовного персоналу, про який ідеться у ст. 33 III Женевської конвенції), є комбатантами, тобто вони мають право брати безпосередню участь у воєнних діях [10]. Отже, основною ознакою комбатанта є його перебування у збройних силах.

Також МГП визнає комбатантами:

1) жителів неокупованої території, які під час наближення ворога озброюються (п. 6 ст. 4 а III Женевської конвенції) [13; 8, с. 35];

членів інших ополчень та добровольчих загонів ( п. 2 ст. 4а III Женевської конвенції) [13].

Наведене формулювання ст. 4а III Женевської конвенції дуже серйозно критикувалося правниками $з$ посиланням на ту обставину, що умова додержання законів та звичаїв війни має дискримінаційний характер порівняно з особами із складу збройних сил, для яких статус комбатанта не пов' язується $з$ вказаною умовою [8, с. 35]. Ці зауваження були враховані у Протоколі I, відповідно до п. 1 ст. 43 якого збройні сили сторони, що перебуває в конфлікті, складаються з усіх організованих збройних сил, груп і підрозділів, що перебувають під командуванням особи, відповідальної перед цією стороною за поведінку своїх підлеглих, навіть якщо ця сторона представлена урядом чи властями, не визнаними супротивною стороною; такі збройні сили підпорядковані внутрішній дисциплінарній системі, яка, поряд з іншим, забезпечує додержання норм міжнародного права, застосовуваних у період збройних конфліктів [10].

Встановлення правового статусу комбатанта є вкрай важливим, оскільки визначатиме, яким чином може бути притягнута до відповідальності особа, залежно від ії правового статусу у збройному конфлікті, за вчинені нею протиправні дії. За висновком Т. Короткого, комбатанти є законними учасниками війни, мають право приймати безпосередню участь у військових діях і відповідно є правомірним об'єктом нападу [14, с. 243]. Комбатант має право застосовувати силу і навіть вбивати, не будучи при цьому притягнутим до персональної відповідальності за насильницькі дії [8, с. 35].

Таким чином, існує основна відмінність між нормами МГП і прав людини: перші дозволяють позбавляти осіб життя в будь-який момент і за будь-яких обставин, грунтуючись лише на статусі особи, а не на іï поведінці. За винятком ситуації, якщо особа має статус horse de combat, тоді правомірність позбавлення ії життя буде грунтуватися винятково на ії поведінці з урахуванням положень статтей 2, 15 ЄКПЛ [15].

Більш того, положення статті 2 слід аналізувати лише з урахуванням положень статті 1 щодо обов' язковості забезпечити кожному в межах своєї юрисдикції права і свободи, визначені в Конвенції [1]. Ця позиція підтверджується також практикою ССПЛ. Так, у справі Al-skeini and others v. the United Kingdom, що вже аналізувалась вище, було зазначено, що обов'язок захищати право на життя згідно зі статтею 2 повинен тлумачитися у поєднанні з загальним обов'язком держави згідно зі статтею 1 Конвенції [3]. При чому, такий підхід є системним, адже його можна відслідкувати також в інших рішеннях ССПЛ. Це, зокрема, рішення Labita v. Italy ma Gldani Congregation of Jehovah's Witnesses v. Georgia $[7$, c. 32]. 
Право на життя не має абсолютного характеру та не містить безумовного захисту життя як такого, на чому наголошує Д. Гом'єн [16]. Правильність такої позиції підтверджується самою Конвенцією, яка містить ряд положень, що передбачають можливість обмеження цього права у разі: захисту від насильства; арешту або втечі особи з місць обмеження волі; придушення повстання чи заворушення; правомірного виконання смертного вироку, який винесений судом в належному порядку, а також через правомірні воєнні дії [1]. Для цілей цього дослідження важливим є визначення категорії «правомірні воєнні дії», яка на думку ряду вчених, стосуються, переважно, міжнародних збройних конфліктів [17]. ЄСПЛ намагається максимально уникати надавати кваліфікацію тим чи іншим конфліктам між державами. Саме цим пояснюється відсутність практики Суду у контексті захисту права на життя при міжнародних конфліктах [15]. Намагаючись максимально уникати застосування норм МГП, Суд змушений був сформулювати власні унікальні підходи в кожній окремій ситуації, не зв' язуючи себе кваліфікацією подій з боку сторін спору [18, с. 271-272].

Разом $з$ тим, ситуація, що склалася із українськими моряками наприкінці 2018 році, які були захоплені в результаті збройного нападу в Азовському морі, щодо якої українським урядом було подано відповідну заяву до ЄСПЛ 7 лютого 2019 року № 55855/18, на нашу думку, може докорінно змінити підхід ЄСПЛ. Тим більше, що існуюча практика ЄСПЛ свідчить, що відсутність офіційного відступу відповідно до частини 2 статті 15 (правомірні воєнні дії) не перешкоджає Суду враховувати контекст та положення МГП при тлумаченні та застосуванні ЄКПЛ [7]. Так, у ряді справ, які стосувалися ситуацій у Чечні та Туреччині, ССПЛ для кваліфікації ситуації і правильному застосуванню ЄКПЛ вимушений був звернутися до Другого Додаткового протоколу до Женевських конвенцій 1949 року і кваліфікувати ситуацію як збройний конфлікт неміжнародного характеру. Зокрема, це справи Esmukhambetov and Others v. Russia [19], Özkan and others v. Turkey [20], Varnava and others v. Turkey [21], Kaya v Turkey [22] та інші. У цих справах Суд зосередився на встановленні фактів порушення урядовими силами норм МГП і саме в світлі норм МГП розцінював наявність порушень ЄКПЛ.

У рішенні Varnava and others v. Turkey Суд зазначив, що стаття 2 Конвенції, в міру можливого, повинна розглядатися в світлі принципів міжнародного права, зокрема, правил міжнародного гуманітарного права, які відіграють необхідну і загальновизнану роль у пом'якшенні звірства та негуманності збройних конфліктів. В зоні міжнародного конфлікту держави-підписанти повинні захищати життя тих, хто не бере чи вже не бере участь у військових діях, що вимагає, зокрема, надання медичної допомоги пораненим; що стосується загиблих, обов'язок звітувати включає в себе належне захоронення їхніх тіл та збір і повідомлення офіційними органами інформації про особи та долі загиблих. У цій справі Уряд-відповідач не надав жодних переконливих матеріалів чи пояснень, які б могли спростувати твердження заявників про те, що згадані особи зникли в секторі, який знаходився під його виключним контролем. Оскаржувані зникнення мали місце за обставин, що ставили під загрозу життя цих осіб, оскільки військові операції супроводжувались арештами та вбивствами у великій кількості. Таким чином, Суд встановив, що стаття 2 Конвенції покладає на державу постійний обов'язок розшукувати зниклих без вісті осіб та звітувати про те, що з ними трапилось.

Показовою є також ще одна справа проти Туреччини, яка стосувалась порушення права на життя під час збройного конфлікту між Туреччиною і Робітничою партією Курдистану, в ході якого було підпалено ряд цивільних об'єктів - Özkan and others v. Turkey. У рішенні по цій справі Суд констатував порушення позитивного зобов'язання держави - невжиття належних заходів щодо встановлення факту завдання шкоди цивільному населенню в результаті вибуху. Крім того, було констатовано відсутність порушення негативного зобов'язання держави, тобто Суд фактично визнав, що завдання шкоди (неминучої та ненавмисної) цивільному населенню та цивільним об'єктам під час збройного конфлікту є правомірним.

Так, Судом було вказано стосовно статті 2 Конвенції (питання про використання сили підрозділом сил безпеки): з урахуванням того, що під час зазначених подій на південному сході Туреччини мали місце серйозні заворушення, що включали збройні конфлікти між силами безпеки і членами Робітничої партії Курдистану, формат тактичного реагування сил безпеки на їх первинний обстріл з боку села, не був непропорційним застосуванням сили і був «абсолютно необхідним», згідно 3 формулюванням статті 2 Конвенції, для захисту життя.

Далі з приводу можливого порушення статті 2 Конвенції Суд в контексті загибелі жителів села констатує, що залишається непідкріпленим доказами той факт, що смерть однієї з жителів сталася в результаті незабезпечення ії належною медичною допомогою з боку сила безпеки. Однак, на думку Суду, груба байдужість, виявлена силами безпеки, призвела до того, що серед мирного населення могли бути жертви перестрілки, тому це прирівнюється до порушення зобов'язання влади охороняти життя людини, що випливає з вимог статті 2 Конвенції. Що ж стосується жителя села, який помер від запалення легенів, перебуваючи під вартою, то було встановлено, що він захворів через те, що 
його змусили босоніж йти по снігу, а також через умови подальшого утримання під вартою. Тому, на думку Суду, владу можна вважати відповідальною за причини його смерті. В обох випадках Суд встановив: прокуратура, яка розслідувала те, що трапилося, не провела ефективне розслідування обставин двох смертей, що прирівнюється до порушення статті 2 Конвенції в ії процесуальному аспекті.

Аналогічну позицію Суд зайняв у справі Ergi v. Turkey, констатувавши у резолютивній частині рішення відсутній факт порушення негативного зобов' язання згідно статті 2 СКПЛ (п. 3 Рішення «не встановлено, що сестра заявника була вбита силами безпеки в порушення статті 2 Конвенції»). Разом $з$ тим, було прийнято одноголосне рішення щодо порушення позитивного зобов' язання (п. 4 Рішення «встановлено порушення статті 2 Конвенції щодо планування та проведення операцій сил безпеки, а також щодо неспроможності органів держави-відповідача проводити адекватне та ефективне розслідування обставини смерті») [23].

Більш детально на змісті позитивного та негативного зобов' язання у контексті статті 2 СКПЛ Суд зупинився у справі Kiliç v Turkey [24]. За фабулою справи - журналісту Кемалю Кілічу неодноразово погрожували позбавити його життя. Відповідно Суд розглядав наскільки такі погрози журналісту були реальними і чи порушила Туреччина відповідні зобов'язання. Суд наголосив, що частина 1 статті 2 Конвенції зобов'язує державу не тільки утримуватися від умисного і незаконного позбавлення життя, але й вживати відповідних заходів для захисту життя тих, хто перебуває під ії юрисдикцією Це включає в себе основний обов'язок держави забезпечити право на життя шляхом запровадження ефективних положень кримінального законодавства для запобігання вчиненню правопорушень проти особи, що повинно підкріплюватися належним функціонуванням правоохоронних органів для запобігання, припинення та покарання порушень прав людини. Це стосується також обов'язку у відповідних обставинах поширювати позитивний обов'язок органів влади на вжиття превентивних оперативних заходів для захисту особи або осіб, чиє життя піддається ризику злочинними діями іншої особи.

Дуже важливим для розуміння змісту позитивного зобов' язання є п. 63 Рішення, де зазначено, що «беручи до уваги труднощі, пов'язані з охороною сучасного суспільства, непередбачуваність людської поведінки та оперативний вибір, який має здійснюватися з точки зору пріоритетів та ресурсів, позитивний обов'язок повинен тлумачитися таким чином, що не накладає неможливого або непропорційного навантаження. на владу. Відповідно, не кожен заявлений ризик для життя може спричинити для органів влади вимогу Конвенції щодо вжиття оперативних заходів для запобігання здійсненню цього ризику. Для того, щоб виникло позитивне зобов'язання, необхідно встановити, що органи влади знали або повинні були знати на момент існування реального і безпосереднього ризику для життя ідентифікованої особи або окремих осіб від злочинних дій третіх осіб і що вони не вжили заходів у межах своїх повноважень, які, на думку обгрунтовано, могли б уникнути цього ризику.

Що стосується негативного зобов' язання держави щодо права на життя, то воно міститься беззастережно лише Протоколі 13 до Конвенції та передбачає заборону на застосування смертної кари всіма країнами - учасниками Ради Свропи, що його підписали, як в мирний, так і у воєнний час.

Таким чином, слід зазначити, що колізії між нормами, спрямованими на захист прав людини, зокрема нормами ЄКПЛ, та нормами МГП є системними. Слід констатувати, що міжнародно-правові норми (ні процесуальні, ні матеріальні) не містять положень щодо порядку взаємодії двох ключових галузей міжнародного права - міжнародного права прав людини та МГП - емпіричним шляхом було встановлено, що стосовно саме права на життя норми МГП є lex specialis. Тобто, якщо порушено норми МГП це обов' язково означає, що порушено норми, що стосуються захисту прав людини [25]. Таким чином, Суд, застосовуючи одночасно норми обох галузей права, виявляє прогалини, які існують, та сприяє взаємопроникненню норм. I для даного випадку - це слід вважати одним із способів прогресивного розвитку міжнародного права в цілому. Тим більше, що норми, обох галузей права спрямовані на захист людей від насильства настільки, наскільки це можливо [17]. Відповідно аналіз практики Європейського суду з прав людини свідчить про постійний пошук Судом підходів до певної конвергенції між нормами норм міжнародного права захисту прав людини та нормами МГП.

1. Конвенція про захист прав людини і основоположних свобод з протоколами. URL: https:// zakon.rada.gov.ua/laws/show/995_004

2. Case of Catan and others v.Republic of Moldova and Russia Applications no. 43370/04, 8252/05 and 18454/06 URL: https://hudoc.echr.coe.int/rus\#\{\%22fulltext\%22:[\% 22Catan\%22],\%22documentcollecti onid2\%22:[\%22JUDGMENTS\%22],\%22itemid \%22:[\%22001-114082\%22]\} 
3. Case of Al-skeini and others v. the United Kingdom Application no. 55721/07. URL: https:// hudoc.echr.coe.int/rus\#\{\%22itemid\%22:[\%22001-105606\%22]\}

4. Case of Issa and others v. Turkey Application no. 31821/96 URL: https://hudoc.echr.coe.int/rus\# \{\%22itemid $\% 22:[\% 22001-67460 \% 22]\}$

5. Конвенція про закони і звичаї війни на суходолі // Офіційний вісник України від 06.01.2017 - 2017 p., № 2.

6. Case of Jaloud v. the Netherlands Application no. 47708/08 URL: https://hudoc.echr.coe.int/app/ conversion $/$ pdf $/$ ?library $=$ ECHR\&id=001-148367\&filename=001-148367.pdf\&TID=qeikrbadtm

7. Case of Hassan v. the United Kingdom Application no. 29750/09 URL :https:/ / hudoc.echr.coe.int/ app $/$ conversion/pdf/ ?library $=$ ECHR\&id=001-146501\&filename $=001-146501 . p d f \& T I D=q y d v i g x s e m$

8. Толочко О.Н. Международное гуманитарное право: Учеб. пособие. - Гродно: ГрГУ, 2003. - 87 с.

9. Процун С.С. Щодо визначення поняття «незаконний комбатант» / С. С. Процун // Порівняльно-аналітичне право. - 2014. - № 2. - С. 372-375.

10. Додатковий протокол до Женевських конвенцій від 12 серпня 1949 року, що стосується захисту жертв міжнародних збройних конфліктів (Протокол I), від 8 червня 1977 року URL: http:/ / zakon2.rada.gov.ua/laws/show/995_199

11. Конвенція про захист цивільного населення під час війни (укр/рос) від 12 серпня 1949 року URL: http://zakon2.rada.gov.ua/laws/show/995_154

12. Манько М. В. «Незаконні комбатанти»: реалії сучасного часу / М. В. Манько // Часопис Київського університету права. - 2013. - № 1. - С. 343-348.

13. Женевська конвенція про поводження з військовополоненими (укр/рос) від 12 серпня 1949 року URL: http://zakon2.rada.gov.ua/laws/show/995_153

14. Короткий Т.Р. Понятие «незаконные комбатанты» / Т.Р. Короткий / / Наукові праці Одеської національної юридичної академії. голов. ред. С. В. Ківалов ; МОН України, ОНЮА. - Одеса : Юрид. л-ра, 2009. - Т. 8. - С. 242-251.

15. Park I. The Right to Life Obligations of States and How to Ensure Compliance. In The Right to Life in Armed Conflict. Oxford University Press, 2018. URL: http://www.oxfordscholarship.com/view/10.1093/ oso/9780198821380.001.0001/oso-9780198821380-chapter-8

16. Гомьен Д. Путеводитель по Европейской конвенции о защите прав человека и основных свобод. Страсбург. 2000.

17. Doswald-Beck Louise. The Right to Life in Armed Conflict: Does International Humanitarian Law Provide all the Answers? International Review of the Red Cross. 2006. 88(864). P. 881-904.

18. Русинова В. Права человека в вооруженных конфликтах: соотношение норм международного гуманитарного права и международного права прав человека: дис. ... канд. юрид. наук: 12.00.10. M., 2015. 466 c.

19. Case of Esmukhambetov and Others v. Russia, Application no. 23445/03 URL: https://hudoc.echr. coe.int/rus\#\{\%22itemid\%22:[\%22001-104159\%22]\}

20. Case of Ahmet Özkan and Others v. Turkey, Application no. 21689/93, URL: https://hudoc.echr. coe.int/rus\#\{\%22itemid $\% 22:[\% 22001-61696 \% 22]\}$.

21. Varnava and Others v. Turkey, Application no. 16064/ 90, 16065/90, 16066/90, 16068/90, 16069/90, 16070/90, 16071/90, 16072/90, and 16073/90, URL: https://hudoc.echr.coe.int/rus\#\{\%22item id \%22:[\%22001-94162\%22]\}

22. Case of Mahmut Kaya v. Turkey, Application no. 22535/93 URL: https://hudoc.echr.coe.int/rus\# \{\%22itemid $\% 22:[\% 22001-58523 \% 22]\}$

23. Case of Ergi v. Turkey, Application no. 66/1997/850/1057 URL: https://hudoc.echr.coe.int/rus\#\{ $\% 22$ itemid $\% 22:[\% 22001-58200 \% 22]\}$

24. Case of Kiliç v. Turkey, Application no. 22492/93 URL: https://hudoc.echr.coe.int/rus\#\{\%22item id\%22:[\%22001-58524\%22]\}

25. Давид Э. Принципы права вооруженных конфликтов / MKKK. 2011. URL: https://www.icrc. $\mathrm{org} / \mathrm{rus} /$ resources/documents/publication/eric-david-principles.htm 


\section{Summary}

The article is devoted to the analysis of the practice of the European Court of Human Rights in the context of the implementation of the norms of international humanitarian law. The key judgments of the European Court of Human Rights concerning violations of Articles 1, 2 and 5 of the Convention for the Protection of Human Rights and Fundamental Freedoms considered by the Court in the context of the implementation of the rules of international humanitarian law were analyzed. In particular, were analyzed the ECHR judgements in the following cases: Catan and others v. Republic of Moldova and Russia; Al-skeini and others v. the United Kingdom; Issa and others v. Turkey; Jaloud v. the Netherlands; Hassan v. the United Kingdom; Labita v. Italy; Gldani Congregation of Jehovah's Witnesses v. Georgia; Esmukhambetov and Others v. Russia; Özkan and others v. Turkey; Varnava and others v. Turkey; Kaya v Turkey; Ergi v. Turkey; Kiliç v Turkey.

In the context of the Court practice under Article 1 of the Convention, it has been established that the ECtHR recognized a number of exceptional circumstances that could lead to the extension of the jurisdiction of the state beyond its own territorial boundaries.

The case-law of the Court also shows that, in case of an international armed conflict, the rights guaranteed by the Convention must be applied in the light of the context and provisions of international humanitarian law. It is stated that there is a fundamental difference between IHL norms and human rights rules: the IHL norms allow to deprive people of life at any moment and under all circumstances, based only on the status of the person, and not on its behavior. The study also analyzed the content of the positive commitment and the negative commitment of the state towards the right to life.

It has been established that the content and the scope of the right to life, as well as the content of the negative, and especially the positive obligations of the state in the implementation of this right, largely depends on: 1) the nature of the conflict (international (non-international) armed conflict, situations of domestic violence, which do not reach the level of armed conflict); 2) the legal status of the subjects and, in some cases, the behavior of such entities.

It has been determined that safeguards under Article 5 of the Convention should be interpreted and applied in the light of the context and the provisions of international humanitarian law. Such provisions are to be interpreted in the light of Article 15 of the Convention, which allows derogations from obligations in case of an emergency.

According to the results of the study, it was found that the conflicts between the human rights protection norms, in particular the standards of the ECHR, and IHL norms, are systemic.

It is noted that the international legal norms (neither procedural nor substantive) do not contain provisions on the interaction between the two key areas of international law - the international human rights protection law and the IHL - it was found empirically that the IHL norms are lex specialis towards right to life. Thus, the Court, applying at the same time the norms of both branches of law, identifies the existing gaps and contributes to the interpenetration of norms.

Accordingly, an analysis of the practice of the European Court of Human Rights shows that the Court has consistently sought approaches to a certain convergence between the norms of international human rights law and IHL norms. 